\title{
Street Children in Alexandria: Profile and Psychological Disorders
}

\author{
Gehan M. Mounir*, Medhat S Attia ${ }^{\dagger}$, Kholoud Y Tayel ${ }^{\star}$
}

\begin{abstract}
Background: Today developed and developing countries are facing the problem posed by street children. The continuous and unrestrained exposure to the street and its associated lifestyles makes these children vulnerable to a range of health, social, and other problems. Objective: The aim of the present work was to assess the profile of street children and their living condition from different aspects, in addition to assessment of some psychological disorders among them. Methods: A cross-sectional study was conducted on 50 street boys present at El-Horreya institute for Children Community Development, which is a non-governmental organization in Alexandria. An equal control group of 50 school boys were selected at random from the first and second grades of one governmental boys preparatory school of the Middle District of Alexandria. Every child was subjected to an interviewing questionnaire. The Arabic version of Revised Ontario Child Health study scale, children Depression Inventory and the Cooper-Smith Self-Esteem Inventory, were used to identify children with conduct disorder, depression, and assess self-esteem, respectively. Anthropometric measurements including weight and height were measured for each street child and BMI was calculated. Results: The present study revealed that more than half of street children (58.0\%) came from large size families, about three-quarters $(72.0 \%)$ reported insufficient income, most of them had low educated parents and unskilled fathers, $80.0 \%$ reported not living with both parents before coming to the institute, and $91.2 \%$ reported bad inter-parental relationship. Family history of drug abuse, alcohol intake, smoking, and imprison were significantly higher among street children compared to school children $(p<0.001)$. The present study showed that $74.0 \%$ of street children were smokers, $22.0 \%$ reported drug abuse, and $90.0 \%$ were dropped out of school. Family violence, beating, and beating without reason significantly increase the risk of being a street child $(\mathrm{OR}=31.90,2.0$, and 44.58 , respectively). The risk of conduct disorder, depression, and low-self esteem were significantly more among street children compared to school children ( $\mathrm{OR}=44.59,14.64$, and 9.66, respectively). The main cause of leaving home was beating, $80.0 \%$ lived in street after leaving home, $72.0 \%$ their main source of living was begging, and most of them faced problems in the street especially with the police. The results revealed that $92.0 \%$ were satisfied with the institute and $86.0 \%$ prefer to stay in the institute than returning to the street. Recommendations: planning programs to prevent, protect, and rehabilitate street children are essential.
\end{abstract}

\section{INTRODUCTION}

The issue of street children continues to attract the attention of social scientists and governmental bodies worldwide. Children who spend their days largely unsupervised in public spaces of urban centers are commonly referred to as "street children". ${ }^{1}$ The International Year of the Child (1979) brought into focus the plight of street and working children, especially in the developing countries. In the context of the developing world, UNICEF (1986), has categorized street

\footnotetext{
${ }^{*}$ Family Health Department (School Health), High Institute of Public Health, Alexandria University, Egypt.

${ }^{\dagger}$ Family Health Department (Mental Health), High Institute of Public Health, Alexandria University, Egypt.
} 
children as: 'children at risk', those who live in families but work on the streets to supplement the family income, 'children on the street', those who have some family support but work on the streets, and 'children of the street', those who live and work on the streets without any family support. ${ }^{2}$ Many of these children survive by begging, theft, prostitution, or some other marginal activity. Others are engaged in occupations such as shoe-shining, selling cigarettes, car washing, etc. They sleep in bus shelters, under bridges, or in old sewage pipes. $^{3}$

The number of street children has increased worldwide and they represent one of our most serious global challenges. Approximately ten million children round the globe are homeless and 150 million spend much of their time on the streets. ${ }^{4}$ The number of street children is a big issue in Egypt and is on the rise. ${ }^{5}$ Estimates on the number of street children range from 200,000 to one million and a quarter of the street child population is believed to be less than 12 years old. ${ }^{5}$
Street children are both victims and barometers of extreme social and economic stress. Their presence is an indication of rapid urbanization, environmental degradation, inequitable distribution of wealth and income, and breakdown of traditional family and community values and structures. ${ }^{6}$ The key factors pushing children onto the streets in Egypt are family breakup (divorce, separation, remarriage, and death), large family size, child abuse and neglect, low income and educational levels, unplanned rural-urban migration, and children's difficulties in coping with the formal school system, increasing the rate of drop-out. ${ }^{7}$

The continuous and unrestrained exposure to the street and its associated lifestyles makes these children vulnerable to a range of health, social and psychological problems. ${ }^{8}$ Studies reported that the use of drugs, violence by police and sexual exploitation constitute important problems among those children..$^{9,10}$ Also street children have a high prevalence of depressive disorder, anxiety, behavioral problems and suicidal attempts. ${ }^{11,12}$ 
United Nations stresses the right of every child to have opportunities for developing physically, mentally, and socially in conditions of freedom and dignity within home and outside. Hence, the problems faced by the street children should be viewed as a human rights issue as exploitation on the street and exposure to violence infringes on their human rights. ${ }^{13}$

It is important that the special problems of this group are recognized so that the City can target its resources on areas most critical to preventing delinquency thereby helping these youth in making a successful transition into adulthood. ${ }^{14}$

The aim of the present work was: To assess the profile of street children and their living condition from different aspects, in addition to assessment of some psychological disorders among them.

\section{MATERIAL AND METHODS}

\section{Study setting and sampling:}

A cross-sectional study was conducted at El-Horreya Institute for Community Development, which is a non-governmental organization in Alexandria. The Institute gives full stay to street children, supply them with clothes, and money, they learn some skills together with reading and writing. All street children present at time of the study and agree to participate were included in the sample. The total sample was 50 street boys. An equal control group of 50 school boys were selected at random from the first and second grades of one governmental boys preparatory school of the Middle District of Alexandria, which was selected randomly out of the seven districts of Alexandria Governorate.

\section{Methods:}

For the conduction of the study, the following tools were used:

1) A pre-designed interviewing questionnaire was used to collect the following data from the street and school children:

a) Socio-demographic data: including, age, family size, income, father education and occupation, mother education, living condition, and inter-parental relationship. Illiterate, read and write, and primary educated parents were considered low educated, preparatory and 
secondary educated parents were considered middle educated, and university and higher educated parents were considered high educated.

b) Family data: family history of drug abuse, alcohol intake, smoking, and imprisonment.

c) Social relations and some characteristics: relation with mother, father and siblings, drug abuse, and smoking behavior.

d) Family violence, type, and tools of punishment.

2) A pre-designed interviewing questionnaire was used to collect the following data from the street children:

a) Causes of leaving home and the ways of coming to the institute.

b) Circumstances of living condition: place of living, source of living after leaving home, and street problems and injuries.

c) Participation in institute activities and beliefs about the institute.

d) Going to school and causes of not going.

3) Psychological tests: Both the street and school children were subjected to psychological tests using the following tools:

\section{A) The Arabic version of Revised Ontario} Child Health study scale ${ }^{15}$

It was used to identify the children with conduct disorder (CD). The scale consists of 12 questions concerning the child behavior and problems they sometimes have. Each question has three choices (no "0", sometimes "1", and always "2") forming a total score that ranges between "0-24". Those who scored above 6 were considered as CD children. ${ }^{16}$

\section{B) The Arabic version of Children Depression Inventory ${ }^{17}$}

It is a self report rating scale to assess depression in children. The scale consists of 27 multiple choice items concerned with symptoms of childhood depression. Each item consists of 3 choices graded from 0 to 2 , with a total score ranging between $0-54$. The cutoff score used was $25 .{ }^{17}$ Those with total score $\geq 25$ were considered depressed.

C) The Arabic version of the Cooper-Smith Self-Esteem Inventory ${ }^{18}$

It is a self report rating scale to assess self-esteem in children. It consists of 25 items. Each item consists of 2 choices with a score of 
$0-1$, and thus the total score ranged between

0-25. Those with total score $\geq 20$ were considered of high self-esteem, $\leq 14$ were considered of low self-esteem and $>14-<20$ were considered average self-esteem. ${ }^{19}$

4) Anthropometric measurements: Weight and height were measured for the street children and BMI was calculated using the formula $\mathrm{BMI}=$ Weight in $\mathrm{kg} /(\text { Height in meter })^{2}$. Those whose $\mathrm{BMI}$ for age was $<5^{\text {th }}$ percentile were considered as underweight, $\geq 5^{\text {th }}$ percentile and $<85^{\text {th }}$ percentile as normal, $\geq 85^{\text {th }}$ percentile and $<95^{\text {th }}$ percentile as overweight, and $\geq 95^{\text {th }}$ percentile as obese..$^{20}$

\section{Statistical analysis:}

The data were coded, entered, and analysed using SPSS (version 10) software program. Mean and standard deviation, chisquared test, and Odd's ratio were used.

\section{RESULTS}

Table 1 shows that the age of street children ranged from 10 to 15 years with a mean age of $12.85 \pm 1.57$ years. The age of school children ranged from 11 to 13 years with a mean age of $12.41 \pm 0.51$ years. More than half of street children (58.0\%) compared to only $22 \%$ of school children came from large size families (i.e., $\geq 6$ ) and the difference was found to be statistically significant $\left(\chi^{2}=13.50, p<0.001\right)$. Insufficient income was reported by about three-quarters of street children $(72.0 \%)$ compared to none of school children reported insufficient income and the difference was statistically significant $\left(\chi^{2}=64.63, \quad p<0.001\right)$. Findings from the respondents' parental background revealed that $80.5 \%$ of fathers of street children compared to only $4.3 \%$ of fathers of school children were of low education and $87.8 \%$ of fathers of street children were unskilled workers compared to only $8.5 \%$ of fathers of school children. The difference was statistically significant $\left(\chi^{2}=59.96\right.$ and 60.53 , respectively, $p<0.001)$. As regards mother education, $93.5 \%$ of mothers of street children were of low education compared to only $8.0 \%$ of mothers of school children. The difference was statistically significant $\left(\chi^{2}=71.03\right.$, $p<0.001)$ 
Concerning the living condition, $80.0 \%$ of street children reported not living with both parents before coming to the institute compared to only $10.0 \%$ of school children. The cause of not living with both parents was mainly divorce in street children (67.5\%) and death in school children (60.0\%). The difference was statistically significant $\left(\chi^{2}=\right.$ 49.49 and 57.52, respectively, $\mathrm{p}<0.001)$. As regards the inter-parental relationship, most of street children (91.2\%) reported bad relationship compared to none of school children and the difference was statistically significant $\left(\chi^{2}=81.49, p<0.001\right)$.

Figure 1 shows the nutritional status of street children. It reveals that $14.0 \%$ were underweight, $84.0 \%$ normal, and $2.0 \%$ overweight.

Table 2 shows that the family history of drug abuse, alcohol intake, smoking, and imprisonment were significantly higher among street children $(38.0 \%, 28.0 \%, 82.0 \%$, and $42.0 \%$, respectively) compared to school children $(0.0 \%, 4.0 \%, 48.0 \%$ and $0.0 \%$ respectively), $\chi^{2}=23.47,10.71,17.70$, and 26.58, respectively, $p<0.001$

Table 3 shows that bad relation with mother, father, and siblings were more significantly reported among street children (23.9\%, $85.4 \%$, and $26.1 \%$, respectively) compared to school children $(0.0 \%, 2.1 \%$, and $6.2 \%$, respectively), $\chi^{2}=43.50,74.75$, and 36.57, respectively, $p<0.001$. The study also revealed that $22.0 \%$ of street children reported drug abuse and $74.0 \%$ were smokers compared to none of school children and the difference was statistically significant $\left(\chi^{2}=\right.$ 12.36 and 58.73 , respectively, $p<0.001$ )

Regarding going to school, it was observed that $90.0 \%$ of street children reported that they did not go to school. The causes of not going to school were in the following order; $57.8 \%$ truancy from school, $17.8 \%$ dismissed by the school authority, $13.3 \%$ the father took them out of school, and lastly $11.1 \%$ didn't go to school due to multiple school exam failure.

Table 4 shows that family violence was reported among $78.0 \%$ of street children compared to only $10.0 \%$ of school children. 
Family violence significantly increased the risk of being street children $(\mathrm{OR}=31.90,95 \%$ $\left.C L=10.40-97.09, \quad \chi^{2}{ }^{M H S}=46.44, \quad p<0.001\right) . \quad$ As regards the type of punishment, beating was reported by all street children (100.0\%) compared to $50 \%$ of school children. Beating significantly increases the risk of being street children. $\quad(\mathrm{OR}=2, \quad 95 \% \mathrm{CL}=1.03-3.88$, $\left.\chi^{2} \mathrm{MHS}=4.17, \mathrm{p}<0.05\right)$. Most of street children (94.0\%) compared to only $10.0 \%$ of school children reported beating using sticks and/or sharp objects. The risk of beating using sticks and/or sharp objects was significantly higher among street children. $(\mathrm{OR}=12.16$, 95\%CL=4.07-35.99, $\left.\quad \chi^{2} \mathrm{MHS}=23.12, \quad \mathrm{p}<0.001\right)$. Beating complication was reported by $90 \%$ of street children compared to only $24.0 \%$ of school children. The risk of beating complications was significantly higher among street children. $(\mathrm{OR}=28.50,95 \% \mathrm{CL}=7.93$ 102.36, $\left.\quad \chi^{2} \mathrm{MHS}=32.91, \quad \mathrm{p}<0.001\right) \quad$ A higher percentage of street children (74.0\%) compared to school children $(6.0 \%)$ reported beating without reason. Beating without reason significantly increases the risk of being street children. $(\mathrm{OR}=44.59,95 \% \mathrm{CL}=12.37$ 157.37, $\left.\chi^{2} \mathrm{MHS}=47.68, p<0.001\right)$

Table 5 shows that nearly three-quarters $(74.0 \%)$ of street children had conduct disorder compared to only $6.0 \%$ of school children. Being street children increases the risk of conduct disorder. (OR=44.59, $\left.95 \% C L=12.37-157.37, \chi^{2} \mathrm{MHS}=47.68, \mathrm{p}<0.001\right)$. The study also revealed that more than half of street children (56.0\%) had depression compared to only $8.0 \%$ of school children. The risk of depression was significantly higher among street children. $\quad(O R=14.64$, $\left.95 \% C L=4.72-44.76, \quad \chi^{2} \mathrm{MHS}=26.20, \quad \mathrm{p}<0.001\right)$. Concerning self-esteem, most of street children (95.2\%) had low self-esteem compared to $58.0 \%$ of school children. The risk of low self-esteem was significantly higher among street children. $\quad(O R=9.66$, $95 \% C L=1.47-60.88, \chi^{2} \mathrm{MHS}=5.98, p<0.01$ )

Table 6 shows that the main causes of leaving home as stated by the children were beating $(44.0 \%)$, bad treatment of stepparent $(30 \%)$, bad treatment of father $(14.0 \%)$, and lastly feeling board at home (12.0\%). The 
main way of joining the institute was through a family member (36.0\%), followed by with colleagues $(28.0 \%)$, supported by staff member from the institute (16.0\%), alone $(16.0 \%)$, and lastly the police $(4.0 \%)$.

Table 7 shows that after leaving home, 80 $\%$ of street children were residing in street and their main source of living (e.g., getting food) was begging $(72.0 \%)$, followed by the institute $(14.0 \%)$, work $(8.0 \%)$, and relatives $(6.0 \%)$. The study also revealed that $80 \%$ of street children faced problems in the street, mainly with the police $(65.6 \%)$, followed by problems with other street children (53.1\%), then problems with people in the street (31.3\%). Nearly half of street children (47.5\%) were subjected to injuries during their stay in the streets.

Table 8 shows that most of street children (94.0\%) participate in institute activities, 94.0\% learn skills and $46.0 \%$ learn reading and writing. Most of them (92.0\%) were satisfied with the institute, $62.0 \%$ had no constrains in the institute, and $78.0 \%$ trust people in the institute. The table also showed that $90.0 \%$ take money from the institute. Also $86.0 \%$ reported that they prefer staying in the institute than staying at home $(14.0 \%)$, or returning to the street $(0.0 \%)$. 

Table 1: Distribution of street and school children according to some socio-demographic characteristics

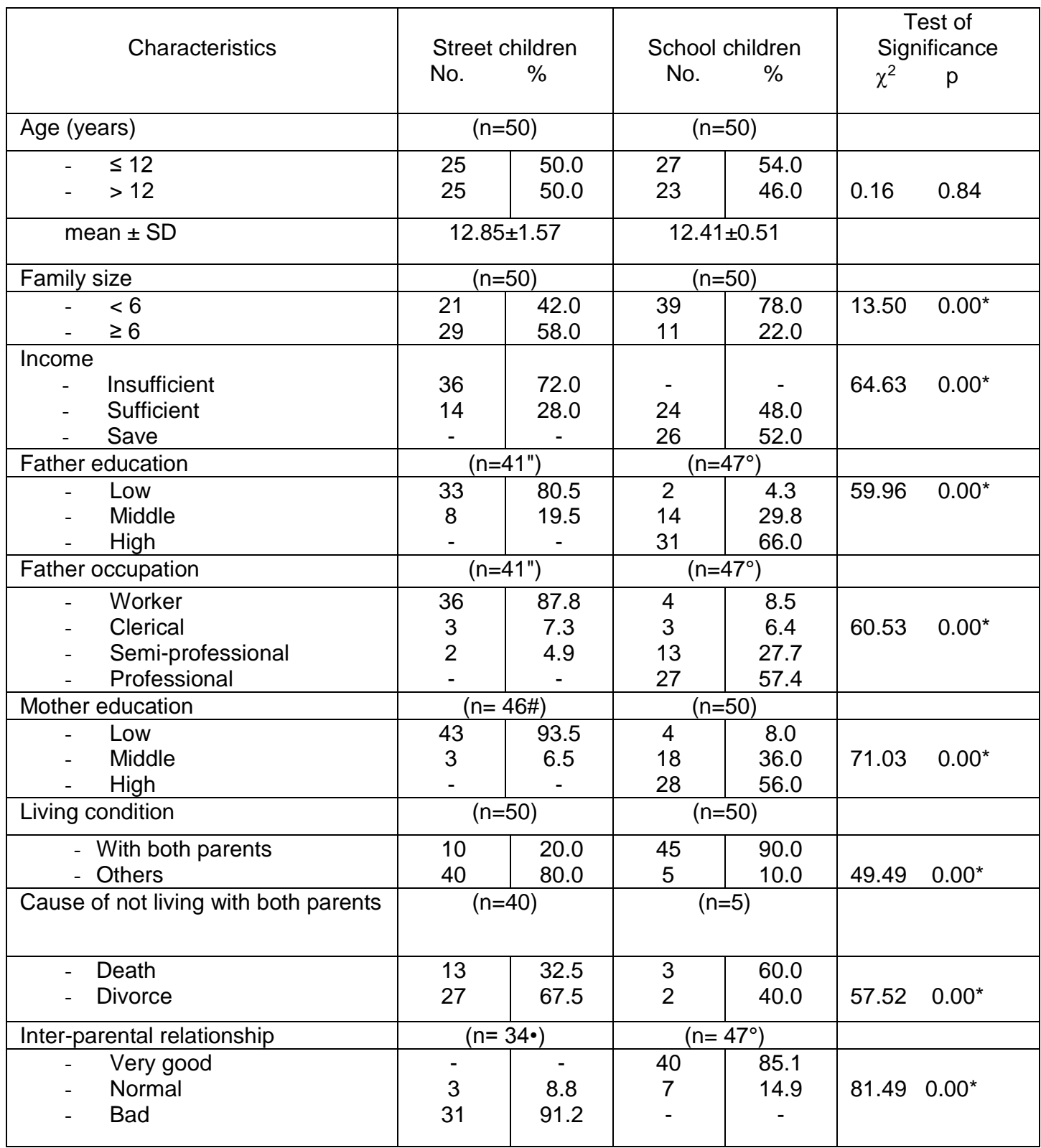

" Excluding 9 street children due to death of their father

- Excluding 3 school children due to death of their father

\# Excluding 4 street children due to death of their mothers

- Excluding 16 street children due to death of either one parent or both parents

* Statistically significant at $p<0.001$ 


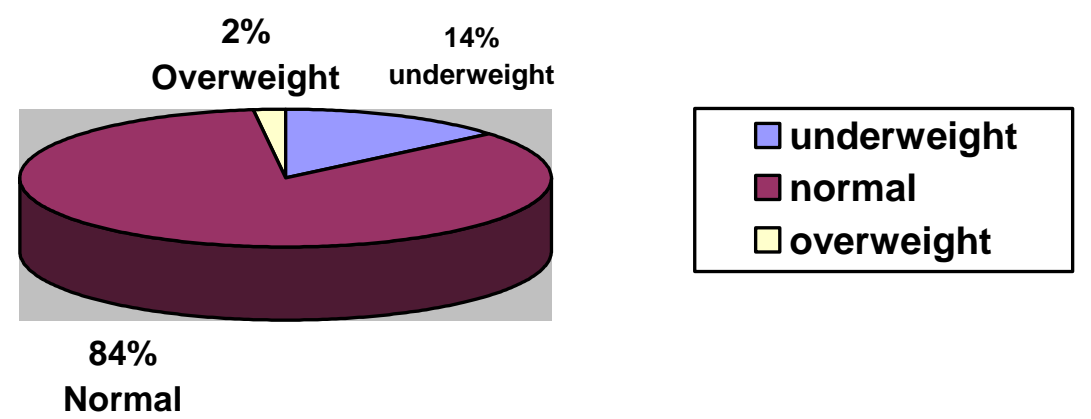

Figure 1

Nutritional status of street children

Table 2: Distribution of street and school children according to family history of drug abuse, alcohol intake, smoking, and imprisonment.

\begin{tabular}{|c|c|c|c|c|c|c|}
\hline Variables & $\begin{array}{l}\text { Stre } \\
\text { No. }\end{array}$ & $\begin{array}{l}\text { Idren } \\
\% \\
\% \\
0)\end{array}$ & $\begin{array}{r}\text { Sch } \\
\mathrm{N}\end{array}$ & $\begin{array}{l}\text { ildren } \\
\text { \%) }\end{array}$ & $\begin{array}{l}\text { Sig } \\
\chi^{2}\end{array}$ & $\begin{array}{l}\text { ist of } \\
\text { ificance } \\
p\end{array}$ \\
\hline $\begin{array}{c}\text { Family history of drug abuse } \\
-\quad \text { Yes } \\
-\quad \text { No }\end{array}$ & $\begin{array}{l}19 \\
31\end{array}$ & $\begin{array}{l}38.0 \\
62.0\end{array}$ & - & 100.0 & 23.47 & $0.00^{*}$ \\
\hline $\begin{array}{c}\text { Family history of alcohol intake } \\
-\quad \text { Yes } \\
-\quad \text { No }\end{array}$ & $\begin{array}{l}14 \\
36\end{array}$ & $\begin{array}{l}28.0 \\
72.0\end{array}$ & $\begin{array}{c}2 \\
48\end{array}$ & $\begin{array}{c}4.0 \\
96.0\end{array}$ & 10.71 & $0.00^{*}$ \\
\hline $\begin{array}{c}\text { Family history of smoking } \\
-\quad \text { Yes } \\
-\quad \text { No }\end{array}$ & $\begin{array}{c}41 \\
9\end{array}$ & $\begin{array}{l}82.0 \\
18.0\end{array}$ & $\begin{array}{l}24 \\
26\end{array}$ & $\begin{array}{l}48.0 \\
52.0\end{array}$ & 17.70 & $0.00^{*}$ \\
\hline $\begin{array}{c}\text { Family history of imprisonment } \\
-\quad \text { Yes } \\
-\quad \text { No }\end{array}$ & $\begin{array}{l}21 \\
29\end{array}$ & $\begin{array}{l}42.0 \\
58.0\end{array}$ & $\begin{array}{c}- \\
50\end{array}$ & 100.0 & 26.58 & $0.00^{*}$ \\
\hline
\end{tabular}

* Statistically significant at $p<0.001$ 
Table 3: Distribution of street and school children according to social relations and some characteristics.

\begin{tabular}{|c|c|c|c|c|c|c|}
\hline \multirow[t]{2}{*}{ Variables } & \multicolumn{2}{|c|}{ Street children } & \multicolumn{2}{|c|}{ School children } & \multicolumn{2}{|c|}{$\begin{array}{c}\text { Test of } \\
\text { Significance }\end{array}$} \\
\hline & No. & $\%$ & No. & $\%$ & $\chi^{2}$ & $p$ \\
\hline Relation with mother & \multicolumn{2}{|c|}{$\left(\mathrm{n}=46^{\#)}\right.$} & \multicolumn{2}{|c|}{$(n=50)$} & & \\
\hline - $\quad$ Very good & 13 & 28.3 & 45 & 90.0 & & \\
\hline - Good & 22 & 47.8 & 5 & 10.0 & 43.50 & $0.00^{*}$ \\
\hline - $\quad$ Bad & 11 & 23.9 & - & - & & \\
\hline Relation with father & \multicolumn{2}{|c|}{$(n=41 \cdot)$} & \multicolumn{2}{|c|}{$(n=47 \cdot)$} & & \\
\hline - $\quad$ Very good & 1 & 2.4 & 40 & 85.1 & & \\
\hline - Good & 5 & 12.2 & 6 & 12.8 & & \\
\hline - $\quad \mathrm{Bad}$ & 35 & 85.4 & 1 & 2.1 & 74.75 & $0.00^{*}$ \\
\hline Relation with siblings & \multicolumn{2}{|c|}{$\left(n=46^{\circ}\right)$} & \multicolumn{2}{|c|}{$\left(\mathrm{n}=48^{\stackrel{\circ}{ })}\right.$} & & \\
\hline - $\quad$ Very good & 8 & 17.4 & 38 & 79.2 & & \\
\hline - Good & 26 & 56.5 & 7 & 14.6 & 36.57 & $0.00^{*}$ \\
\hline - $\quad$ Bad & 12 & 26.1 & 3 & 6.2 & & \\
\hline Drug abuse & \multicolumn{2}{|c|}{$(n=50)$} & \multicolumn{2}{|c|}{$(\mathrm{n}=50)$} & & \\
\hline - Yes & 11 & 22.0 & - & - & & \\
\hline$-\quad$ No & 39 & 78.0 & 50 & 100.0 & 12.36 & $0.00^{*}$ \\
\hline Smoking behavior & \multicolumn{2}{|c|}{$(n=50)$} & \multicolumn{2}{|c|}{$(n=50)$} & & \\
\hline - Yes & 37 & 74.0 & - & - & & \\
\hline$-\quad$ No & 13 & 26.0 & 50 & 100.0 & 58.73 & $0.00^{*}$ \\
\hline Going to school & \multicolumn{2}{|c|}{$(\mathrm{n}=50)$} & \multicolumn{2}{|c|}{$(\mathrm{n}=50)$} & & \\
\hline $\begin{array}{ll}- & \text { Yes } \\
- & \text { No }\end{array}$ & $\begin{array}{c}5 \\
45 \\
\end{array}$ & $\begin{array}{l}10.0 \\
90.0\end{array}$ & $\begin{array}{l}50 \\
-\end{array}$ & $\begin{array}{c}100.0 \\
-\end{array}$ & & - \\
\hline Causes of not going to school & \multicolumn{2}{|c|}{$(n=45)$} & & & & \\
\hline - Truancy & 26 & 57.8 & - & - & & \\
\hline $\begin{array}{l}\text { - Dismissed by school } \\
\text { authority }\end{array}$ & 8 & 17.8 & - & - & & - \\
\hline $\begin{array}{l}\text { - Father took his child out of } \\
\text { school }\end{array}$ & 6 & 13.3 & - & - & & \\
\hline - Multiple school exam failure & 5 & 11.1 & - & - & & \\
\hline
\end{tabular}

\# 4 street children their mother's were dead.

- 9 street children and 3 school children their father's were dead.

- 4 street children and 2 school children didn't have siblings.

* Statistically significant at $p<0.001$ 
Table 4: Distribution of street and school children according to family violence, type, and tools of punishment.

\begin{tabular}{|c|c|c|c|c|c|c|c|}
\hline Variable & \multicolumn{2}{|c|}{$\begin{array}{l}\text { Street children } \\
\text { No. }\end{array}$} & \multicolumn{2}{|c|}{$\begin{array}{l}\text { School children } \\
\text { No. } \%\end{array}$} & OR & $\chi^{2} \mathrm{MHS}$ & $\begin{array}{l}95 \% C L \\
\text { LL-UL }\end{array}$ \\
\hline Family violence & \multicolumn{2}{|c|}{$(\mathrm{n}=50)$} & \multicolumn{2}{|c|}{$(\mathrm{n}=50)$} & & & \\
\hline $\begin{array}{ll}- & \text { Yes } \\
- & \text { No }\end{array}$ & $\begin{array}{l}39 \\
11\end{array}$ & $\begin{array}{l}78.0 \\
22.0\end{array}$ & $\begin{array}{c}5 \\
45\end{array}$ & $\begin{array}{l}10.0 \\
90.0\end{array}$ & $\begin{array}{c}31.90 \\
1\end{array}$ & $46.44^{\star \star \star}$ & $10.40-97.09$ \\
\hline Type of punishment & \multicolumn{2}{|c|}{$(n=86 \bullet)$} & \multicolumn{2}{|c|}{$(n=61 \bullet)$} & & & \\
\hline $\begin{array}{ll}- & \text { Beating } \\
- & \text { Other means }\end{array}$ & $\begin{array}{l}50 \\
36\end{array}$ & $\begin{array}{l}100.0 \\
72.0\end{array}$ & $\begin{array}{l}25 \\
36\end{array}$ & $\begin{array}{l}50.0 \\
72.0\end{array}$ & $\begin{array}{c}2.0 \\
1\end{array}$ & $4.17^{*}$ & $1.03-3.88$ \\
\hline Tools of beating & \multicolumn{2}{|c|}{$(n=64) \cdot$} & \multicolumn{2}{|c|}{$(n=27)^{\circ}$} & & & \\
\hline $\begin{array}{ll}- & \text { Hands } \\
- & \text { Sticks and/or sharp } \\
\text { objects }\end{array}$ & $\begin{array}{l}17 \\
47\end{array}$ & $\begin{array}{l}34.0 \\
94.0\end{array}$ & $\begin{array}{c}22 \\
5\end{array}$ & $\begin{array}{l}44.0 \\
10.0\end{array}$ & $\begin{array}{c}1 \\
12.16\end{array}$ & $23.12^{\star * *}$ & $4.07-35.99$ \\
\hline Beating complications & \multicolumn{2}{|c|}{$(n=50)$} & \multicolumn{2}{|c|}{$\frac{1}{(n=25)}$} & & & \\
\hline $\begin{array}{ll}- & \text { Yes } \\
- & \text { No }\end{array}$ & $\begin{array}{c}45 \\
5\end{array}$ & $\begin{array}{l}90.0 \\
10.0\end{array}$ & $\begin{array}{c}6 \\
19\end{array}$ & $\begin{array}{l}24.0 \\
76.0\end{array}$ & $\begin{array}{c}28.50 \\
1\end{array}$ & $32.91^{* \star *}$ & $7.93-102.36$ \\
\hline Beating without reason & \multicolumn{2}{|c|}{$(n=50)$} & \multicolumn{2}{|c|}{$(n=50)$} & & & \\
\hline $\begin{array}{ll}- & \text { Yes } \\
- & \text { No }\end{array}$ & $\begin{array}{l}37 \\
13\end{array}$ & $\begin{array}{l}74.0 \\
26.0\end{array}$ & $\begin{array}{c}3 \\
47\end{array}$ & $\begin{array}{l}6.0 \\
94.0\end{array}$ & $\begin{array}{c}44.59 \\
1\end{array}$ & $47.68^{\star \star \star}$ & $\begin{array}{l}12.37- \\
157.37\end{array}$ \\
\hline
\end{tabular}

- The increase number due to multiple responses

- 25 school children were not subjected to beating

*** Significant at $p<0.001$

* Significant at $p<0.05$

Table 5: Distribution of street and school children according to psychiatric problems and self esteem

\begin{tabular}{|c|c|c|c|c|c|c|c|}
\hline \multirow[t]{2}{*}{ Psychiatric problems } & \multicolumn{2}{|c|}{$\begin{array}{c}\text { Street children } \\
(\mathrm{n}=50)\end{array}$} & \multicolumn{2}{|c|}{$\begin{array}{c}\text { School children } \\
(n=50)\end{array}$} & \multirow[t]{2}{*}{ OR } & \multirow[t]{2}{*}{$\chi^{2} \mathrm{MHS}$} & \multirow{2}{*}{$\begin{array}{l}95 \% C L \\
\text { LL-UL }\end{array}$} \\
\hline & & & No & $\%$ & & & \\
\hline $\begin{array}{c}\text { Conduct disorder } \\
-\quad \text { Yes } \\
-\quad \text { No } \\
\end{array}$ & $\begin{array}{l}37 \\
13\end{array}$ & $\begin{array}{l}74.0 \\
26.0 \\
\end{array}$ & $\begin{array}{c}3 \\
47\end{array}$ & $\begin{array}{c}6.0 \\
94.0\end{array}$ & $\begin{array}{c}44.59 \\
1\end{array}$ & $47.68^{\star \star \star}$ & $\begin{array}{l}12.37- \\
157.37\end{array}$ \\
\hline $\begin{array}{cl}\text { Depression } \\
-\quad \text { Depressed } \\
-\quad \text { Non-depressed }\end{array}$ & $\begin{array}{l}28 \\
22\end{array}$ & $\begin{array}{l}56.0 \\
44.0\end{array}$ & $\begin{array}{c}4 \\
46\end{array}$ & $\begin{array}{c}8.0 \\
92.0\end{array}$ & $\begin{array}{c}14.64 \\
1\end{array}$ & $26.20^{\star \star \star}$ & $\begin{array}{l}4.72- \\
44.76\end{array}$ \\
\hline Self-esteem & & $21 \cdot)$ & & & & & \\
\hline $\begin{array}{ll}- & \text { Low } \\
- & \text { Average } \\
- & \text { High } \\
\end{array}$ & $\begin{array}{c}20 \\
1 \\
- \\
\end{array}$ & $\begin{array}{c}95.2 \\
4.8 \\
-\end{array}$ & $\begin{array}{l}29 \\
14 \\
7 \\
\end{array}$ & $\begin{array}{l}58.0 \\
28.0 \\
14.0\end{array}$ & $\begin{array}{c}9.66 \\
1\end{array}$ & $5.98^{\star *}$ & $\begin{array}{l}1.47- \\
60.88\end{array}$ \\
\hline
\end{tabular}

- 29 street children refused to fill the questionnaire

*** Significant at $p<0.001$

** Significant at $p<0.01$ 
Table 6: Distribution of street children according to causes of leaving home and the ways of coming to the institute as stated by children.

\begin{tabular}{|l|c|c|}
\hline \multirow{2}{*}{ Causes of leaving home } & \multicolumn{2}{|c|}{ Street children } \\
& No. & \% \\
\hline - Beating & 22 & 44.0 \\
- Bad treatment of stepparent & 15 & 30.0 \\
- Bad treatment of father & 7 & 14.0 \\
- Feeling board at home & 6 & 12.0 \\
\hline Ways of joining the institute & & \\
- A family member & 18 & 36.0 \\
- With colleagues & 14 & 28.0 \\
- Staff member from the institute & 8 & 16.0 \\
- Alone & 8 & 16.0 \\
- Police & 2 & 4.0 \\
\hline
\end{tabular}

Table 7: Distribution of street children according to circumstances of living condition

\begin{tabular}{|l|c|c|}
\hline \multirow{2}{*}{ Place of living after leaving home } & \multicolumn{3}{|c|}{ Street children } \\
No. & \multicolumn{3}{|c|}{$(\mathrm{n}=50)$} \\
\hline - Street & 40 & 80.0 \\
- Institute & 7 & 14.0 \\
- Others & 3 & 6.0 \\
\hline Source of living after leaving home & \multicolumn{3}{|c|}{$(\mathrm{n}=50)$} \\
\hline - Begging & 36 & 72.0 \\
- Institute & 7 & 14.0 \\
- Work & 4 & 8.0 \\
- Relatives & 3 & 6.0 \\
\hline Problems in street & \multicolumn{3}{|c|}{$\left(\mathrm{n}=40^{*}\right)$} \\
\hline - No & 8 & 20.0 \\
- Yes & 32 & 80.0 \\
\hline Type of Problems & \multicolumn{3}{|c|}{$\left(\mathrm{n}=48^{\circ}\right)$} \\
\hline - Problems with the police & 21 & 65.6 \\
- Problems with street children & 17 & 53.1 \\
- Problems with people & 10 & 31.3 \\
\hline Street injuries & \multicolumn{3}{|c|}{$\left(\mathrm{n}=40^{*}\right)$} \\
\hline - No & 21 & 52.5 \\
- Yes & 19 & 47.5 \\
\hline
\end{tabular}

* 10 children didn't go to street

- Multiple responses 
Table (8): Distribution of street children according to participation in institute activities and their beliefs about the institute.

\begin{tabular}{|l|c|c|}
\hline \multicolumn{1}{|c|}{ Variables } & No. & \% \\
\hline Participation in institute activities & 3 & 6.0 \\
- No & 47 & 94.0 \\
- Learning skill & 23 & 46.0 \\
- Learning reading and writing & \multicolumn{2}{|c|}{} \\
\hline Satisfaction with the institute & 46 & 92.0 \\
\hline - Yes & 4 & 8.0 \\
- No & \multicolumn{2}{|c|}{} \\
\hline Feeling constrained in the institute & 19 & 38.0 \\
\hline - Yes & 31 & 62.0 \\
- No & 39 & 78.0 \\
\hline Trust people in the institute & 11 & 22.0 \\
\hline - Yes & \multicolumn{2}{|c|}{} \\
- No & 45 & 90.0 \\
\hline Taking daily money from the institute & 5 & 10.0 \\
\hline - Yes & 43 & 86.0 \\
- No & 7 & 14.0 \\
\hline Which is more useful & - & - \\
\hline - Stay in the institute & \multicolumn{2}{|c|}{} \\
- Stay at home & Stay in street & \multicolumn{2}{|c|}{} \\
\hline \multicolumn{2}{|l|}{} \\
\hline
\end{tabular}

\section{DISCUSSION}

The presence of vast numbers of children in the streets in unsupervised and unprotected situations reflects an unprecedented social problem of profound deprivation and inequality. ${ }^{21}$ A 'National Strategy to Protect, Integrate and Rehabilitate Street Children' was launched by the National Council of Childhood and Motherhood (NCCM) in March 2003. ${ }^{7}$ The aim of the present work was to assess the profile of street children and their living conditions from different aspects. In addition to assessment of some psychological disorders among them which is important in planning programs to prevent, protect, and rehabilitate them. In consistence with other studies, ${ }^{22,23}$ the present study revealed that more than half of street children belonged to families having six or more children, and most of them had low educated parents and unskilled fathers. It can be noticed also that about three-quarters of street children came from low income home 
backgrounds. The lower the family income level, the more the children are exposed to the risk of abandoning the home to seek their needs in the street. ${ }^{24}$

The present study found that higher proportions of street children experienced difficult circumstances at home; most of them reported not living with both parents before coming to the institute which was mainly due to divorce followed by having a parent who had died. Also bad inter-parental relationship was evident among most of parents of street children. The study done by Matchinda $(1999)^{24}$ in Cameroon revealed that $71.4 \%$ of street children came from unstable home backgrounds where parents are either temporally or permanently living in separation, or where parental quarrels and fights are very frequent. In a study done on working and street children in Khartoum, they found that many had experienced the death of at least one of their parents, most often a father. ${ }^{1}$ It is, therefore, not surprising that these children were mostly reared either by single parent, stepparent, or relatives. This parental neglect is evidenced, and may explain why most of the youth were driven to the street for economic survival.

Concerning the nutritional status of street children, the present study showed that $14.0 \%$ were underweight. Several studies found that street children have been found to be seriously underweight. ${ }^{23,25}$ This could be explained by the prevalence of malnutrition together with chronic diseases among street children. In contrast, other studies ${ }^{26,27}$ have found the health and nutrition status of street children to be better than their socioeconomic peers. A possible explanation is their better financial resources than those of children who rely solely on their parents, consequently giving them better access to food.

Family history of drug abuse, alcohol intake, smoking, and imprisonment were significantly higher among street children of the present study compared to school children. The results of the study done by Early $(2005)^{28}$, in USA suggested that the probability of being homeless increased if the head of the family had a problem with alcohol 
or illicit drugs. It is reasonable to assume that the risk taking behaviors are more common among families of street children due to bad living conditions as marital disruption, poverty, and domestic violence.

The present study also revealed that, about three quarters of street children were smokers and nearly a quarter of them reported drug abuse. The study done by Poornima (2007) ${ }^{14}$ in India showed that more than $50 \%$ of boys had used one or more substance while out on the streets (e.g. smoking was the commonest). Other studies reported $69-90 \%$ substance use.29, 30 The lower rate of drug abuse in the present study could be explained by the fact that those children were institutionalized. Isolation from family increasing the chances of frequent use of drugs and of performing other delinquent activities. Moreover, they generally reported more experience of familial abuse, and/or parental death or homelessness. Such prior trauma may in turn have contributed to the drug abuse. It is difficult to determine the degree to which substance abuse is a cause or a consequence of homelessness. ${ }^{31}$

Bad relations with mother, father, and siblings were more significantly reported among street children of the present study especially relation with father, which was one of the reported causes of leaving home.

Most of street children in the present study reported not going to school, the causes were mainly truancy, followed by dismissed from school, father took him out of school, and lastly multiple failure in exams. The study done by Olley $(2006)^{32}$ on street youth in Nigeria revealed that $46 \%$ of the youth had a history of school refusal; $27 \%$ had a history of suspension from school; and $47 \%$ had a history of truancy from school. Street children tend to have lower intellectual functioning and decreased academic achievement. Homelessness would probably impact upon cognitive development and function, not least through such proximal causes as malnutrition, physical, sexual, and substance abuse, neurological and psychiatric disorder. ${ }^{33}$ Another explanation for the increase rate of 
school drop out among street children is poverty.

Childhood maltreatment is pervasive and known to be associated with a variety of adverse effects on health and social functioning. ${ }^{34}$ The present study showed that family violence, beating especially using sticks and/or sharp objects, the presence of beating complications (e.g., contusions, wounds, and fractures), and beaten without reason significantly increase the risk of leaving home to the streets. Although rates of runaway adolescent reports of abusive family backgrounds vary widely across studies, all these indicate severe risk for physical and sexual abuse. ${ }^{35,36}$

It seems reasonable to suggest that street children will have varying degrees of individual and family pathology in their backgrounds that may make them vulnerable to current or future mental health problems. The present study revealed that the risk of conduct disorder, depression, and low self-esteem were significantly higher among street children. In a study done by Kerfoot et al., (2007) $)^{37}$ in
Ukraine, behavioral and emotional difficulties, particularly depression were a marked feature of the street children. Various studies have reported estimates of depression among this population ranging from $20-80 \% .^{36,38}$ In the study done by Sarbjeet et al., (2004) ${ }^{36}$ in India among street children they found that about $69 \%$ had behavioral problems, $81 \%$ of children had antisocial behavior, $7.8 \%$ were neurotic. One explanation for the high rate of conduct disorder may be the fragmented family background and consequent lack of social support and socialization. ${ }^{32}$ This obviously has implications when implementing life skills education, especially in addressing the emotional needs of these children. ${ }^{32}$ Also low self-esteem has been found to be one important cause of psychological disorders among these children. ${ }^{39}$

Understanding the causes of street homelessness is important since the street homeless often faces the most severe living conditions and are more difficult to target for outreach and other types of programs designed to aid the very poor and the 
homeless. Knowing which households are most likely to end up outside the shelter system will allow policy makers to target aid better toward that group. ${ }^{28}$ The present study revealed that the main possible causes of leaving home were beating, followed by bad treatment of stepparent, bad treatment of father, and lastly feeling board at home. Other studies reported physical abuse at home as a major cause. ${ }^{23,40}$ It seems possible that street boys' families were poor and this contributed to their street life, but they did not report this because they did not consider themselves to be poor, or they felt other reasons were more important.

The main way of joining the institute as revealed by the present work was through a family member, through a colleague, member from the institute, alone, and lastly the police. Coming through a family member confirms that familial breakdown is a main possible cause of leaving home. Although children coming alone to join the institute was a small percentage but it emphasises the importance of awareness of those children about the available institutions that can apply services for them.

Although most street children wander in that environment to work out of economic necessity, they are exposed to a setting that has none of the safety or security of a conventional work place. ${ }^{21}$ The present study revealed that after leaving home, the majority of street children (80.0\%) lived in street and their main source of living was begging. They faced problems in the street, mainly with the police and about half of them were subjected to street injuries. The study done by Poornima $(2007)^{14}$ found that $10.5 \%$ of street children complained of harassment by the police. In Egypt legislation is a problem in that it still permits police to arrest children who are not suspected of crimes but who are 'vulnerable to delinquency'. ${ }^{7}$

The present study revealed that most of street children were satisfied with the institute. They participated in institute activities, which was mainly in the form of learning skills in addition to reading and writing. Most of them felt not constrained and they take money from 
the institute. The incentives, facilities, and safe environment inside the institute let most of street children prefer staying in the institute than returning to the street.

\section{Conclusion:}

More than half of street children belonged to families having six or more children, and most of them had low educated parents and unskilled fathers. It can be noticed also that most of them came from low income home backgrounds with bad inter-parental relationship. Positive family history of drug abuse, alcohol intake, smoking, and imprisonment was reported. Most of street children reported smoking and school drop out and about a quarter of the street children reported drug abuse. Family violence and physical abuse were reported by most of them. The risk of conduct disorder, depression, and low self-esteem were higher among street children than school children. The most important cause of leaving home was beating by the caregiver. Most of them live in street after leaving home and their main source of living was begging. Majority of them face problems in street especially with the police. Satisfaction with the institute was reported by most of them as they prefer to stay in the institute than going back to the street.

\section{RECOMMENDATIONS:}

- The risk factors emerging from this study can be useful in identifying highrisk families; whose children are likely to be street children and hence can be of use in implementing prevention and rehabilitation programs

- Implementing a life skill program to address the conduct disorders may help to increase the well being of street children.

\section{Community based rehabilitation program is suggested. Under this program, all street children should be gathered in a community setting and exposed to an array of skills.}

- Support NGOs in finding suitable locations for more drop-in centers for street children. Also cooperative efforts 
of public and private organizations are also required.

- Health education of the parents is important to decrease family violence and child abuse.

\section{REFERENCES}

1. Plummer ML, Kudrati M, Yousif ND. Beginning street life: Factors contributing to children working and living on the streets of Khartoum, Sudan. Children and Youth Services Review. 2007; 29: 1520-36.

2. Kombarakaran FA. Street children of Bombay: their stresses and strategies of coping. Children and Youth Services Review. 2004; 26: 853-71.

3. Bibars E. Street children in Egypt: from the home to the street to inappropriate corrective institutions. Environment and Urbanization. 1998; 10(1): 201-16.

4. Vahdani P, Hosseini S, Gachkar L, Sharafi K. Prevalence of hepatitis B, hepatitis $\mathrm{C}$, human immunodeficiency virus, and syphilis among street children residing in southern Tehran, Iran. Arch Iranian Med. 2006; 9(2):153-5.

5. United Nation Office on Drug and Crime. Egypt: Street children and substance abuse. Available from: http://www.unodc.org/newsletter/en/pers pectives/0601/page006.html

6. Silva TL. Preventing child exploitation on the streets in the Philippines. Lancet. 2002; 360: 1507.

7. Information about Street Children Egypt. "A Civil Society Forum for North Africa and the Middle East on Promoting and Protecting the Rights of Street Children", 3-6 March 2004, Cairo, Egypt. Available from: http://www.streetchildren.org.uk/reports/ Egypt\%20Child.doc.
8. Morakinyo J, Odejide AO. A community based study of patterns of psychoactive substance use among street children in a local government area of Nigeria. Drug and Alcohol Dependence. 2003; 71: 109-16

9. Nappo AR, Galduroz SA, Mattei. Use of drugs among street children in Brazil. Journal of Psychoactive Drugs. 1997; 29(2): 185-92.

10. Noell JW, Ochs LM. Relationship of sexual orientation to substance abuse, suicidal ideation, suicide attempts and other factors in a population of homeless adolescents. Journal of adolescent health. 2001; 29(1):31-6.

11. Menke EM, Wagner JD. A comparative study of homeless, previously homeless and never homeless school aged children's health. Issues in Comprehensive Pediatric Nursing. 1998; 20(3): 153-73.

12. AmeryJ, Tomkin A, Victor C. The prevalence of behavioral problems among homeless primary school children in an outer London borough. Public Health. 1995; 109: 421-4.

13. World Declaration on the Survival, Protection and Development of Children: Agreed to at the World Summit for Children on 30 September 1990. Available from: http://www.undocuments.net/wsc-dec.htm.

14. Poornima, T. Life on streets. Indian $\mathrm{J}$ Pediatr. 2007; 74:283-6.

15. Boyle $\mathrm{MH}$, Offord DR, Racine $\mathrm{Y}$, Fleming JE, Szatmari P, Sanford M. Evaluation of the Revised Ontario Child Health Study Scales. J Child Psychol Psychiat. 1993; 34: 189-213.

16. Tayel KY, Attia M, Mahdy N, Eldawaiaty AA. Conduct disorders among secondary school students in Alexandria. Presented in "The first UAE International School Health Conference". Abu Dhabi. January, 2002.

17. Abou Nazel M. A study of depression among Alexandria preparatory school adolescents. Ph.D. thesis in Mental 
Health: University of Alexandria, High Institute of Public Health, 1990.

18. Mousa FA, Desouky MA. Manual of Cooper-smith self-esteem Inventory. ElNahda, El-Masria. Cairo. 1981.

19. Mounir GM. Study of the problem of obesity among school students in Alexandria. Ph.D. thesis in School Health: University of Alexandria, High Institute of Public Health, 1996.

20. Ogden LC, Kuczmarski RJ, Flegal KM, Mei Z, Guo S, Wei R, et al. Centers for Disease Control and Prevention 2000 growth charts for the United States: improvments to the 1977 National Centers for Health Statitics version. Pediatrics. 2000; 109: 45- 61.

21. Rizzini I, Lusk M. Children in the streets: Latin America's Lost Generation. Children and Youth Services Review. 1995; 17(30: 391-400.

22. Aderinto A A. Social correlates and coping measures of street-children: $A$ comparative study of street and nonstreet children in South-Western Nigeria. Child Abuse \& Neglect. 2000; 24(9): 1199-213.

23. Alia $M$, Shahabb $S$, Ushijimaa $H$, Muynckc A. Street children in Pakistan: A situational analysis of social conditions and nutritional status. Social Science \& Medicine. 2004; 59:1707-17

24. Matchinda $B$. The impact of home background on the decision of children to run away: The case of Yaounde City street children in Cameroon. Child Abuse \& Neglect. 1999; 23(3):245-55.

25. Ayaya $S \mathrm{O}$, Esamai $\mathrm{F} O$.Health problems of street children in Eldoret, Kenya. East African Medical Journal. 2001; 78(12), 624-9.

26. Gross R, Landfried B, Herman S. Height and weight as a reflection of the nutritional situation of school aged children working and living in the streets of Jakarta. Social Science and Medicine. 1996; 43(4): 453-8.

27. Panter-Brick C, Todd A, Baker R. Growth status of homeless Nepali boys: Do they differ from rural and urban controls? Social Science and Medicine. 1996; 43(4): 441-51.

28. Early D. An empirical investigation of the determinants of street homelessness. Journal of Housing Economics. 2005; 14: 27-47.

29. Kipke MD, Montgomery SB, Simon TR, Iverson EF."Substance abuse" disorders among runaway and homeless youth. Subst Use Misuse, 1997 Jun; 32(7-8) : 969-86.

30. WHO. Working with street children: Understanding substance use among street children. A training package on substance use, sexual, and reproductive health including HIV/AIDS and STDs. Geneva: WHO; 2000.

31. Mallet S, Rosenthal D, Keys D. Young people, drug use and family conflict: Pathways into homelessness. Journal of Adolescence. 2005, 28: 185-99.

32. Olley BO. Social and health behaviors in youth of the streets of Ibadan, Nigeria. Child Abuse \& Neglect. 2006; 30: 27182.

33. Parks RW, Stevens RJ, Spence SA. A systematic review of cognition in homeless children and adolescents. J R Soc Med. 2007; 100(1): 46-50.

34. Briere J, Elliott D M. Prevalence and psychological sequelae of self-reported childhood physical and sexual abuse in a general population sample of men and women. Child Abuse and Neglect. 2003; 27: 1205-22.

35. Kurtz P, Kurtz G, Jarvis S. Problems of maltreated runaway youth. Adolescence. 1991; 26: 544-55.

36. Sarbjeet K, Sharma N, Shivananda J, Saha R, Ingle GK. Mental health status of runaway adolescents. Indian $\mathrm{J}$ Pediatr. 2004;71(5):405-9.

37. Kerfoot M, Koshyl V, Roganov O, Mikhailichenko K, Gorbova I, Pottage D. The health and well-being of neglected, abused and exploited children: The Kyiv Street Children Project. Child Abuse and Neglect. 2007; 31: 27-37.

38. Reilly JJ, Herrman HE, Clarke DM, Neil CC, McNamara CL. Psychiatric 
disorders in and service use by young homeless people. Medical Journal of Australia. 1994; 161(70): 429-32.

39. Pearce J. Child health surveillance for psychiatric disorder: Practical guidelines. Archives of Diseases in Childhood. 1993;69: 394-8.
40. Lalor K J. Street children a comparative perspective. Child Abuse and Neglect. 1999; 23(8), 759-70. 